\title{
Establishment of Two Rats Strains for Testing Coat Color Genes
}

\author{
Junzo YAMADA and Kazuo NAKAJIMA \\ Institute of Laboratory Animals, Faculty of Medicine,
} Kyoto University, Kyoto 606, Japan.

(Received for publication: May 6, 1976)

\begin{abstract}
Two tester strains of the rats for testing coat color genes wese established. The names, the origins and the genotypes of the rats were as follows: (1) abh (F4) Origin : selected from $\left(\mathrm{BN} / \mathrm{fMai} \times \mathrm{Kyo}:\right.$ Wistar) $\mathrm{F}_{2}$. Genotype : C/C, a/a, b/b, h/h. (2) bhd (F2) Origin: selected from $\left(a b h \times\right.$ Tester Moriyama) $F_{2}$. Genotype: $C / C, a / a, b / b, h / h, D / d^{*}$ and $\mathrm{C} / \mathrm{C}, \mathrm{a} / \mathrm{a}, \mathrm{b} / \mathrm{b}, \mathrm{h} / \mathrm{h}, \mathrm{d} / \mathrm{d}$.

(*: not determined but have found no linkage with other coat color genes).
\end{abstract}

\section{2 系統の毛色遺伝子ティト用ラットの作出}

\author{
山田 淳三・中島 一男 \\ 京都大学医学部附属動物実験施設
}

近年になってラットにおいても近交系の数が増加し， また近交系ラットの使用数む免疫学的研究を始めとし， 各方面に㧊いて増加している。近交系ラットのリストと しては Jay [3], Robinson [5], Festing \& Staats [2], Festing [1] があるが，てのうち最む新しいものには 109 の系統が記載されている。しかしこれらの系統のリスト にはまだ標識遺伝子の記録は少ない。

近交系を維持して行くためには標識遺伝子を確認して おくことが重要であるが，ラットの系統にはアルビノが 多く，そのためにも先づ毛色遺伝子を調べておくことが 必要であろう。マウスに执いては簡単には DBA 系の利 用，更には近藤・江崎 [4] が育成した TES-I, TES-II を用いることができる。しかしラットにおいては Tester Moriyama があるだけで, しかもこの系統はB 遺伝子 を持っているので b 遺伝子の同定は困難である。

筆者らはラット毛色用テスターとして $\mathrm{a}$ 遺伝子座, b 遺伝子座, $\mathrm{h}$ 遺伝子座, 更に $\mathrm{d}$ 遺伝子座にある遺伝子を 同定できる 2 系統を育成したので報告する。

\section{育成された系統:}

1. 系統名 $: \mathrm{abh}$

起源: BN/fMai（遺伝子型 : C/C, a/a, b/b, H/H) および Kyo：Wistar（遺伝子型：c/c，a/a, B/B, $\mathrm{h} / \mathrm{h}$ )

間の交雑 $\mathrm{F}_{2}$ より分離育成。 遗伝子座 : C/C, a/a, b/b, h/h 維持方法：兄弟交配（現在 F4）

維持機関：京都大学医学部附属動物実験施設 (山田淳 三)

2. 系統名 : bhd

起源 : abh（遺伝子型 : C/C, a/a, b/b, h/h, D/D) および Tester Moriyama（遺伝子型：C/C, a/a, $\mathrm{B} / \mathrm{B}, \mathrm{h} / \mathrm{h}, \mathrm{d} / \mathrm{d}$ ) 間の交雑 $\mathrm{F}_{2}$ より分離育成。 ただし Tester Moriyamaのd遺伝子については未 確認であるが，他の毛色遺伝子座との連関は認めら れていない。

遺伝子型 : C/C, a/a, b/b, h/h, D/d および C/C, $\mathrm{a} / \mathrm{a}, \mathrm{b} / \mathrm{b}, \mathrm{h} / \mathrm{h}, \mathrm{d} / \mathrm{d}$

維持方法: 兄妹交配 (現在 F2), $\mathrm{d}$ 遺伝子座は強制的 にヘテロで維持。

維持機関 : 京都大学医学部附属動物実験施設 (山田淳 三)

考 察:

これら abh 系, bhd 系の命名はそれぞれの系統の保持 する遺伝子から取ったあのである。

bhd 系の保持する d 遺伝子については未確定であるが， 
ラットにはての Blue dilution (d) の他に Fawn (f), Pink-eyed yellow(p), Red-eyed y llow(r), Ruby eye $(\mathrm{Cr})$ 等の毛色を淡くする遺伝子が報告されている。乙 のうち $\mathrm{f}$ は $\mathrm{a}$ と， $\mathrm{p}, \mathrm{r}$ は $\mathrm{c}$ と連関があると報告されてお

り [5], Ruby eye はC として c series に含まれてい る [6]。bhd 系の持つ $\mathrm{d}$ 遺伝子は $\mathrm{a}$ および $\mathrm{c}$ と連関が認 められていないし, また $\mathrm{c}$ 遺伝子と復対立の関係にない ので， $\mathrm{f}, \mathrm{p}, \mathrm{r}$ および $\mathrm{Cr}$ とは異なる座位の遺伝子である と考えられる。今回は一応 $\mathrm{d}$ として取扱ったが, 将来は っきりと確かめる予定である。

bhd 系においては d 遺伝子座を強制的にへテロにした が，乙れは $b / b, d / d$ と $B / d, d / d$ の区別が非常に困難 であり, $\mathrm{d} / \mathrm{d}$ の形で維持すると, むし $\mathrm{B}$ 遺伝子が混入し たり b 遺伝子が突然変異した場合摘発が困難なため, 常 に約半数の仔は $\mathrm{b} / \mathrm{b}, \mathrm{D} / \mathrm{d}$ として brown の色を確認す るための処置である。

\section{謝辞}

BN 系を分与頂いた中野健司博士（北里大医）および Tester Moriyama 系を分与頂いた西村正彦博士（和歌山医大）に厚く 御礼申し上げる。
文 献:

[1] Festing, M. (1975). In International index of laboratory animals, 3rd edition, 42-46.

[2] Festing, M. \& Staats, J. (1973). Transplantation, 16, 221-245.

[ 3 ] Jay, G. E. (1963). In Methodology in mammalian genetics, Burdette, W. J., editor, Holden Day, San Francisco, 83-123.

[ 4] 近藤恭司 · 江崎孝三郎 (1961). 実験動物, 11, 194-195.

[5] Robinson, R. (1965). In Genetics of the norway rat. Perganon Press, Oxford, 18-20, 672-675.

[6] Searle, A. G.(1968). In Comparative genetics of coat colour in mammals. Logos Press, London, 97-100. 